Volume 1

Issue 1 Transformative Possibilities:

Transcending Interlocking Boundaries

\title{
Not Quite Formal: Theorizing the Informal Labor Market Experiences of "Documented" Immigrant Workers
}

Carrie Cobb

Portland State University

Follow this and additional works at: https://pdxscholar.library.pdx.edu/mcnair Let us know how access to this document benefits you.

\section{Recommended Citation}

Cobb, Carrie (2004) "Not Quite Formal: Theorizing the Informal Labor Market Experiences of “Documented” Immigrant Workers," PSU McNair Scholars Online Journal: Vol. 1: Iss. 1, Article 9. https://doi.org/10.15760/mcnair.2005.48 
Portland State University McNair Research Journal 2004-2005

Not Quite Formal: Theorizing the Informal Labor Market Experiences of “Documented" Immigrant Workers

by

Carrie Cobb

Faculty Mentor: Leopoldo Rodriguez

Citation: Cobb, Carrie. Not Quite Formal: Theorizing the Informal Labor Market Experiences of "Documented" Immigrant Workers. Portland State University McNair Scholars Online Journal, Vol. 1, 2004-2005: 48-73. 


\title{
Not Quite Formal: Theorizing the Informal Labor Market Experiences of "Documented" Immigrant Workers
}

\author{
by Carrie Cobb \\ Faculty Mentor : Leopoldo Rodreiguez
}

Scholarly research on labor markets and immigration is extensive, yet narrowly conceived. Labor economists have focused on the examination of the effect of immigration on the labor market for native workers (see Briggs (2003) and Borjas, Freeman and Katz (1996)). However, the labor market experiences of undocumented immigrant workers, the workings of informal labor markets, particularly in urban areas, and consequences for informal workers remain virtually unexplored.

To better understand the interactions between work and worker, this study focuses on the structure of informal labor markets for immigrant workers. This analysis is based on a series of qualitative interviews of undocumented restaurant workers in Portland, OR. This paper begins by discussing the current understanding of informality in labor markets in industrialized cities. Theoretical limitations of the common perception of informality are addressed and proposals presented for increased theoretical specificity, which generates several working hypotheses as to the dynamics of informal urban labor markets. These hypotheses are analyzed using case-study methodology examining the restaurant industry in Portland, OR and Mexican immigration to Oregon based on a series of interviews. The paper concludes with findings and suggestions for future research.

\section{Understandings of Informal Labor Markets}

Informality is a widely used, but little theorized concept in the scholarly literature. In exploring informality in advanced economies, researchers have often focused on attempting to estimate the size of the informal economy. While valuable to understand the breadth of informal 
work, Enrico Marcelli (2004, p. 3) notes this concentration causes most research to overlook questions on the "character, sources and consequences of informal employment."

The few researchers grappling with the complexity of describing and analyzing the informal labor market face the difficulty of defining what the "informal economy" is, exactly. Colin C Williams and Jan Windebank (1998) represent one train of thought which defines informality narrowly, as "the paid production and sales of goods and services that are unregistered by, or hidden from the state." Other researchers, such as David Simcox (1997) set forth a broader understanding of informality as any type of transaction in which legal regulations are violated.

The different understandings of informality come from the very broadness of the activities that occur outside of the traditional formal economy. Some of these activities are illicit—most are not. Across the globe people inhabit radically different environments that, as Alejandro Portes and Manuel Castells (1989) point out, share certain characteristics in organization. Therefore, Castells and Portes show that informality cannot be too rigidly defined-street vendors scraping by and moonlighting professionals both live within the informal economy. It is this economic activity, they conclude, that is linked by one thing: "it is unregulated by the institutions of society, in a legal and social environment in which similar activities are regulated” (1989).

These definitions have subtle differences that make the classification of work by undocumented immigrants difficult. Their labor is registered by the state, and it is, at least to some extent, regulated. However, the very act of working for undocumented immigrants is a violation of labor laws, and is therefore distinct from formal employment. Because of this, some researchers, such as David Simcox (1997) and Enrico Marcelli (2004), categorize unauthorized immigrants in the informal economy. Simcox notes that the US Department of Labor's definition of "informality" includes any institution that escapes or circumvents rules, regulations, rights and enforcement 
penalties. He concludes that the violation of labor laws intrinsic in employing unauthorized workers places the worker within the informal economy.

Marcelli (2004, p. 4) measures occupations' informality in California by an estimation of the percentage of unauthorized Mexican immigrants working within the industry. In this classification, "occupations with at least twice the proportion of unauthorized immigrants than average are considered to be niches of lower-wage informal employment." Marcelli notes that unauthorized Mexican workers frequently work in conditions where labor laws are violated, a claim supported by Simcox. Simcox reports that the "percentage of illegal aliens claiming to have been denied legally required wages and hours was four and a half times the rate of such complaints for the U.S. workforce as a whole" (1997, 263).

While the common understanding of informality includes all unauthorized workers, in practice research on informality tends to focus on workers that are not only working illegally, but are also untaxed, unregulated and completely hidden by that state. Most empirical research on the characteristics of the informal labor markets in the U.S. has concentrated on highly informal occupations such as domestic work (Hondagneu-Sotelo, Hagan, and Rosales); street vending (Weber); construction (Lopez-Garza) and day labor (Valenzuela). Researchers interested in these labor markets have focused their studies on cities with high proportions of immigrants, such as Miami (Stepick), New York (Sassen-Koob), Houston (Hagan) and Los Angeles (Valenzuela, Lopez Garza, Weber, and Rosales).

\section{Hypotheses:}

The understanding of informal labor markets does little to illuminate the complexities of the labor market that undocumented immigrants face. Undocumented immigrant labor is not homogeneous, and variations in formality within the informal labor markets affect workers' employment strategies and outcomes. Furthermore, descriptors such as informal become less 
descriptive when used to try to convey the complexity of the ways in which documentation, labor laws, and employment arrangements interact. The difficulty in defining informality rests in the breadth of arrangements included.

Undocumented workers have diverse labor experiences, yet with overlapping characteristics. Informality is not experienced as clearly differentiated from formal labor, but rather as a spectrum of experiences ranging from the most informal types of labor to work better characterized as semiformal.

Therefore, I propose the use of a category called semi-formal labor that includes the labor market arrangements at the formal end of the informal spectrum illustrated in Figure 1 below. Key distinctions include the use of false work permission and taxed labor. It appears that access to false papers creates distinct outcomes for semi-formal workers not captured by the current division between informal and formal work.

Figure 1: Spectrum of Formality in the Labor Market

\begin{tabular}{|c|c|c|c|c|}
\hline $\begin{array}{l}\text { A } \\
\text { Formal } \\
\end{array}$ & $\begin{array}{l}\text { B } \\
\text { Semi-formal }\end{array}$ & $\begin{array}{l}\text { C } \\
\text { Semi-informal }\end{array}$ & $\begin{array}{l}\text { D } \\
\text { Informal }\end{array}$ & $\begin{array}{l}\mathbf{E} \\
\text { Informal }\end{array}$ \\
\hline $\begin{array}{l}\text { >Steady } \\
\text { employment } \\
\text { >Taxes deducted } \\
\text { >Legal } \\
\text { documentation } \\
\text { 'Workplace that } \\
\text { respects all labor } \\
\text { laws }\end{array}$ & $\begin{array}{l}\text { >Steady } \\
\text { employment } \\
\text { >Taxes deducted } \\
\text { >False } \\
\text { documentation } \\
\text { >Workplace that } \\
\text { respects most } \\
\text { labor laws }\end{array}$ & $\begin{array}{l}\text { >Steady } \\
\text { employment } \\
\text { >Some taxes } \\
\text { deducted } \\
\text { >False } \\
\text { documentation } \\
\text { >Workplace that } \\
\text { respects some } \\
\text { labor laws }\end{array}$ & $\begin{array}{l}\text { >nsteady } \\
\text { employment } \\
\text { >No taxes } \\
\text { deducted } \\
\text { >False } \\
\text { documentation } \\
\text { >Frequent abuse } \\
\text { of labor laws }\end{array}$ & $\begin{array}{l}\text { >Unsteady } \\
\text { employment } \\
\text { >No taxes } \\
\text { deducted } \\
\text { >No } \\
\text { documentation } \\
\text { >Frequent abuse } \\
\text { of basic labor } \\
\text { laws such as } \\
\text { workmen's } \\
\text { compensation } \\
\text { and payment }\end{array}$ \\
\hline
\end{tabular}

Semi-formal workers have distinct work experiences and hence different concerns than other informal workers. Therefore, they often will utilize different employment strategies. These 
strategies could have possible long-term impacts that constrain their future options, and hence deserve examination. In exploring the labor issues that arise for semi-formal workers, three hypotheses emerge:

1.) Semi-formal labor is characterized by uncodified (not based on a set of laws) yet often mutually beneficial employer/employee relations

2.) Networks are crucial in facilitating semi-formal labor relationships through access to the employment, documentation and information necessary for unauthorized workers.

3.) Semi-formal workers pay taxes, yet generally have limited understanding of their tax obligations and rights.

\section{Methodology:}

These hypotheses arose from structured conversations with semi-formal restaurant workers in Portland, OR. The conversations were the heart of a case study of undocumented, Mexican migrant workers employed in restaurants in Portland, Oregon during the summer of 2004 . I interviewed 12 people, eight men and four women. Interviewees were located in two ways, (1) as a snowball sample that started with an acquaintance from seven years of employment in a Portland restaurant, and (2) from respondents to requests posted in a neighborhood Mexican store. All interviews were in Spanish, in person, and lasted for an average of one hour, for which interviewees were paid $\$ 20$.

Questions were based on a questionnaire, but to maintain a natural environment questions were not always asked in order. All questions were open-ended, and many follow up questions were asked. The purpose of the interviews was not to generate systematic data for quantitative analysis, but rather to deepen the interviewers' understanding of semi-formal labor markets.

\section{The Restaurant Industry in Portland, OR}


The restaurant industry offers a large number of low-skill, low-wage jobs to the residents of the city of Portland. Restaurant employment is characterized by irregular hours, few benefits, and little job security. The work is physically demanding-restaurant staff experience extended periods of stress, high temperatures, heavy lifting, hours on their feet and repetitive movements over the course of the workday.

The sector is broken down into two kinds of restaurants-counter service and full service. Counter service covers all establishments where customers order food at a counter, either for take out or to eat inside. This category includes franchises of national fast food establishments, and their local equivalents. Full service restaurants are characterized by table service and a strict separation between kitchen staff and wait-staff.

Fast food employment includes managers, cashiers, and cooks, though workers usually are trained in multiple positions within the restaurant. Full service restaurant jobs can be classified as management, the "front of the house"-reception, waiters and bartenders, and the "back of the house"- cooks and dishwashers. Front of the house jobs include hosting, bussing tables, serving, and running food. Back of the house jobs involve dishwashing, food preparation, pantry cook, line cooks, and in more expensive establishments a chef and sous chef. Most often income is substantially higher in front of the house positions.

Full Service restaurants tend to have two distinct job ladders—a "back of the house" job ladder, and a "front of the house" job ladder. There is virtually no horizontal mobility between the two ladders, except in very small establishments where employees are cross-trained in various aspects of the restaurant. Unauthorized Mexican workers usually enter back of the house positions due to limited English proficiency and limited restaurant experience. Thomas Bailey (1985) found that in New York City, immigrants worked in kitchen jobs, while the front of the house was dominated by white, adult native-born and European men. 
Figure 2: Restaurant Job Ladders

\begin{tabular}{|l|l|}
\hline BACK OF HOUSE & FRONT OF HOUSE \\
\hline Kitchen Manager/ Chef & Floor Management \\
$\uparrow$ & $\uparrow$ \\
Sous Chef & Bartender \\
$\uparrow$ & $\uparrow$ \\
Line Cook & Servers \\
$\uparrow$ & $\uparrow$ \\
Prep Cook & Bussers/Food Runners \\
$\uparrow$ & $\uparrow$ \\
Dishwasher & Host \\
\hline
\end{tabular}

Restaurant work is a classic example of secondary sector employment (see Reich et al 1973). In addition to limited mobility, restaurant wages tend to be low, particularly in the back of the house. Van Giezen (1994) finds the wages to be particularly low in fast food jobs-his study concludes that the wages of fast food workers are tied to the minimum wage and wage increases occur only when the minimum wage is raised. Furthermore, fast food and restaurant jobs have few benefits, such as health care, retirement, vacation and sick pay. Tenure in a job has little impact on pay or benefits.

Table One: Average restaurant employee wages in 2003

\begin{tabular}{||l|l|l|l||}
\hline \hline AREA & EMPLOYMENT & PAYROLL & AVERAGE PAY \\
\hline $\begin{array}{l}\text { Portland PMSA, } \\
\text { Oregon Portion }\end{array}$ & 54,723 & $\$ 748,078,394.00$ & $\$ 13,670.00$ \\
\hline Oregon & 110,077 & $\$ 1,396,286,310.00$ & $\$ 12,685.00$ \\
\hline
\end{tabular}

Source: Oregon Employment Department, Oregon Labor Market Information System "Industry Report: NAICS 722- Food Services and drinking places" 2003

Many immigrants find work in restaurants. John F. Love (1986) estimates that the first job for 1 in 15 immigrant workers is at one fast food chain-McDonald's. The Pew Hispanic Center 
2004-2005 survey of Mexican immigrants applying for the matricula consular found a significant percentage of workers in hospitality (hotel, restaurant and bars). In New York, 26 percent of workers worked in hospitality, in Chicago 17 percent, and in Los Angeles 13 percent (Suro 2005).

The accessibility of restaurant work to immigrant labor can be partly explained by a large number of entry level positions that do not require English fluency. Furthermore, the employment is relatively steady, and the pay typical of urban service sector employment. Restaurant jobs are comparable with employment in hotel maintenance, janitorial staff, and warehouses as semi-formal labor with low pay, little opportunity for advancement and a high number of immigrant workers.

Table 2 shows the number of workers of Mexican descent in "Food Preparation and Serving Related Occupations" in the Portland urban area in 2000. People of Mexican descent were only 6\% of the population, yet comprised $14 \%$ of the food preparation workforce.

Table 2: Employment in "Food Preparation and Serving Related Occupations" in Portland, OR.

\begin{tabular}{|l|l|l|l||}
\hline & Male & female & Total \\
\hline $\begin{array}{l}\text { Total Number of Workers in } \\
\text { "Food Preparation and Serving } \\
\text { Related Occupations" in } \\
\text { Portland }\end{array}$ & 17,773 & 21,740 & 39,513 \\
\hline Number Mexican & 3,579 & 1,948 & 5,527 \\
\hline $\begin{array}{l}\text { Percentage Mexican of total } \\
\text { number of food preparation } \\
\text { workers }\end{array}$ & $9.05 \%$ & $4.93 \%$ & $13.98 \%$ \\
\hline $\begin{array}{l}\text { Percentage Mexican of total } \\
\text { population }\end{array}$ & - & - & $5.8 \%$ \\
\hline
\end{tabular}

Source: Author's calculation based on US Census 2000, Summary File 3

\section{Immigration to Portland, OR}

\footnotetext{
${ }^{1}$ The matricula consular is an identity card issued by the Mexican government. The card has a photograph and the holders U.S. address. The matricula is accepted as identification to establish local address, and in 2003 the U.S. Treasury ruled to allow the card to be used to open bank accounts. The matricula does not confer the legal right to reside or work in the United States (Suro 2005)
} 
Mexican immigration to Portland has dramatically increased since the early 1990s. The 2000 Census showed a significant upsurge in Mexican people living in Portland, OR.

Table 3: Population of Portland, OR

\begin{tabular}{||l|l|l|l||}
\hline & 1990 & 2000 & percent increase \\
\hline $\begin{array}{l}\text { Total Population "All" } \\
\text { of Portland }\end{array}$ & $1,172,158$ & $1,583,138$ & $135 \%$ \\
\hline $\begin{array}{l}\text { Total Population } \\
\text { "Mexican" in Portland }\end{array}$ & 25,787 & 92,021 & $356.85 \%$ \\
\hline
\end{tabular}

Source: Author's calculations based on US Census 2000, Summary File 3

A large portion of the foreign-born population in Oregon is estimated to be undocumented. Jeffrey S. Passell (2005) estimates, based on 2000 Census data, that 30-39 percent of Oregon's foreign-born population is undocumented.

\section{Preliminary Findings}

\section{1.) Semi-formal labor is characterized by uncodified yet often mutually beneficial} employer/employee relations.

Many Mexican immigrants arrive in the United States planning to return home in a few years. Douglas S Massey explains that as temporary workers, migrants are often concerned with a financial goal_-target earning-but over time this goal changes as migrants settle into the receiving community (Massey et. al. 2002). The initial mindset of workers may affect the way migrants approach employment. Michael J Piore (1979) argues that new immigrants do not define themselves in context of their employment, but rather in accordance with their role in the home community. Therefore, low status and insecure employment are perceived as less important to a new temporary worker than a more established employee.

With a target earning strategy, workers have distinctly different objectives from other workers. Target earners often want to maximize the hours they work, allowing them to earn as much money as possible in a short a period of time. Long hours are also beneficial to target earners, 
as there is less time to spend earnings. In addition, many new migrants do not have the same lifestyles as more established workers; they do not have family with them, or obligations in the U.S. beyond work.

Hence, even though overtime pay is mandatory when an employee works more than 40 hours a week, a target earner might not find overtime laws in their short term best interest. This was evident in the interviews I conducted. Most participants worked more than 40 hours, but with hours spread over two jobs, making them ineligible for overtime pay. However, two participants consistently worked more than ten hours overtime in one job. Both workers were "target earners"- they wanted to earn money for specific goals and return to Mexico. They both had children in Mexico and were in the process of building houses. These workers preferred to work long hours at one job because they were able to work more hours without the search and travel costs of a second or third job. They were spared the difficulties associated with juggling different work schedules. Insisting on overtime pay could have resulted in a decline of work hours to 40.

However, not all workers were pleased when employers did not pay the required overtime. Two workers who only occasionally worked over forty hours a week without overtime pay felt that the employer was not treating them correctly. In this situation, the workers received no benefit from extra hours as they already had a second part time job.

Another mutually beneficial yet not codified arrangement observed was non-payment of minimum wage. One worker reported initially receiving less than minimum wage when he began his first job in the United States. However, since he was paid in cash during that period he took home higher pay than he would have received if taxes had been deducted from the minimum wage. Payment in cash eroded his legal protection, but he preferred the take home higher pay in that situation. 
The interactions between worker and employer that arise from these diverse employment strategies are far more complex than the stereotypical image of the victimized, undocumented immigrant facing the abusive employer. While fundamental labor laws are disregarded, the actual relationships formed are mutually symbiotic relationships with benefits for both parties. However, these relationships are not between equals_- the employer still has more power than the worker.

Labor laws are beneficial for workers and employers because they set a standard for conduct that is applicable in varying professions, and they protect workers from the vagaries of employers in a relationship in which both sides do not share the same power. Semi-formal employees engage in a significant trade off when they enter into uncodified relationships that undermine the protection they are given by labor law. These protections include eligibility for unemployment benefits and workmen's compensation, protection from harassment and discrimination, and overtime pay.

As temporary migrants settle, a change in strategy can be anticipated. Settlement means beginning a family, or bringing family from Mexico. Long hours and limited protections are no longer sustainable. The benefits from uncodified working relationships disappear as workers develop new strategies.

\section{2.) Networks are crucial in facilitating semi-formal labor relationships through} access to the employment, documentation and information necessary for unauthorized workers.

Networks are one of the key ingredients that allow semi-formal labor relationships to function. A network is the web of social relationships that connect people-ties of kinship, friendship, or shared geographic origin (Massey et .al 1993, Massey 1997). Accessing documentation, obtaining employment, and achieving schedule flexibility are facilitated by a strong and wide network. These networks often are composed of family, close friends, and a broader range of weak ties with people of similar ethnic or geographic origin. 
The value of a network depends on a variety of factors. The first is network size, as a larger network is better equipped to provide resources than a smaller one. Another important variable described by Enchautegui (2002) is the quality of the network members. Network member's duration of US residence, employment status, and gender affect the level of assistance they can provide a new migrant. Davis, Stecklov and Winters (2002) extend this analysis to include the interrelationships of the network, such as friendship, kinship, or shared country of origin. In their analysis, stronger social relationships increase the level of assistance forthcoming from a network.

For a migrant, social networks are crucial for success. As Munshi (2003) notes, a lack of information about labor markets increases the value of network connections. New migrants rarely have sufficient information on the labor market to obtain desirable employment. Therefore, the value to a new migrant of the information and assistance of a network connection is a determining factor in employment in the receiving country.

One of the initial roles a network fulfills for a semi-formal laborer is the resources and knowledge to obtain false documentation. False documents can be purchased inexpensively, ranging from $\$ 50.00$ for a social security card to $\$ 80.00$ for a card showing legal residence. Since the passage of the Immigration Reform and Control Act of 1986, employers are breaking the law if they knowingly hire an undocumented immigrant. False papers either fool employers, or provide them with a plausible avenue to deny wrong-doing.

Second, a network assists in obtaining employment. Most undocumented immigrants are hesitant to approach an unknown prospective employer. The first reason for this is a language barrier-it is hard to seek employment when the employer doesn't speak Spanish. The second reason is the fear that an unknown person may inspect documentation too carefully. Third, many immigrants do not understand the job hunting process in the United States when they first arrive, as the application and interview process is different in Mexico. 
The wait to obtain initial employment varied greatly. As the study progressed, I began to notice differences in time spent initially unemployed and the number of contacts within the community upon arrival. This is illustrated by the reply of one participant to my query about the difficulties in finding jobs:

"Pues, para mí, yo creo que tengo un poco de suerte encontrar trabajo rápido, tal vez. porque tengo muchos amigos".

"Well, in my case, I am pretty lucky in finding jobs quickly, maybe because I have lots of friends"

One woman, who ultimately found work in a fast-food establishment, did not find a job for a year. Upon arrival she had two contacts, an uncle and a cousin. On the other hand, other arrivals quickly found work. One man began work within weeks due to the contacts he had-eight people from his town already worked in restaurants in Portland and through them he found work. While luck, aggressiveness and other factors affect the time spent obtaining employment, it appears that people who enter into a large network are able to find work quicker than those with a small network.

Gender is a significant factor in the functioning of immigrant networks. Researchers such as Hondagneu-Sotelo (1994) and Hagan (1994) have noted that networks are often segregated by sex. The four women I interviewed all worked in fast-food. Unlike the male workers, who had found their jobs through a network, two of the women went to the restaurant and filled out an application, one with the assistance of her husband who spoke some English. The other two relied on networks. In contrast to some of the established male networks I observed, finding multiple jobs for newcomers in a matter of weeks; the females spent long times waiting for their first job. The women I spoke with had few family members when they arrived, and those family members were older male relatives. While few contacts appear to be a contributing factor to finding employment, it 
was not the only one. I observed that men with limited contacts found employment quicker than women.

Networks also facilitate vacation time and sick leave. Workers cover each others' shifts, and when a worker returns to Mexico for a visit, they sometimes find a friend or family member to work their schedule and hold their job. One example of this was two brothers interviewed. One had recently returned to Mexico for a three month vacation. His brother replaced him during this time, so upon reentry to the United States he reclaimed his previous job. Another example of interchangeability is that many participants asked friends and relatives to cover their shifts when they need time off. These transactions often occurred between the migrants themselves, eliminating the need to negotiate with the employer. A third example of interchangeability is that migrants often find replacements for openings in their jobs before the employer is aware of an opening. In this way, immigrants assist friends and family obtain employment.

These strategies strengthen the role of networks, as job security and flexibility depend upon the migrants themselves instead of the employer. Workers receive assistance from each other, and assist others when they are able. This reciprocity brings more available resources to the network, making information and references for employment available. Furthermore, migrants' obligations increase when they help each other maintain and find employment.

Networks, as valuable as they are in assisting new migrants, face limitations. First, a network composed of strong ties versus weak ties can lead to a lack of occupational mobility as the only opportunities opened by a network are low wage and low skill job opportunities. Hagan (1998) observed an example of this in her study of Mayan domestic workers' networks. She found that networks developed into a hindrance, as their integration into a domestic household meant that they did not form "horizontal links of exchange" with non-Maya. Mayan female domestic workers were 
isolated into one household and unable to form the type of relationships that would increase their income potential.

Networks also leave newcomers vulnerable to being taken advantage of by more established migrants. An example of this was noted by Hondagneu-Sotelo (2001) through her observation of instances of newcomers working with established migrants for extremely low rates. In exchange, established migrants promised to give new migrants experience and help finding a job. However, established migrants would often not assist the newcomer gain employment, but rather use their labor to increase their own wages.

Networks can also cause employees to absorb employment costs traditionally paid by the employer. Fred Krissman (2000) writes that often labor recruited through friends is more malleable and costs less to the employer, as the worker and the person who brought them in feel a sense of mutual obligation. The established worker will absorb costs of training by observing and helping the new worker learn the job. At the same time, the new worker will not complain about unfair working conditions, but rather will work very hard and without complaint in order not to damage the reputation of his or her friend. Eventually, if the new worker finds a better job and votes with his or her feet by leaving, the employer's access to a network of migrant workers cushions loss from turnover and hiring.

\section{3.) Semi-formal workers pay taxes, yet often have limited understanding of their tax}

\section{obligations and rights.}

One of the characteristics of a semi-formal worker is the payment of taxes. These taxes include federal, state and social security taxes. Payment of taxes is one way in which society decides whether or not a group of people is a 'drain' on the system—one of the most common arguments levied against undocumented immigrants is the cost they incur to government. Semi-formal workers pay a variety of taxes, yet have limited understanding of how to file taxes and claim refunds. This 
limited understanding not only deprives them of money they are entitled to, but also may make it difficult when they attempt to legalize their status. In addition, their above-ground economic activity places them at risk of discovery and termination by employers due to actions taken by the federal government such as Social Security "no-match" letters.

Undocumented workers still have the obligation to file their taxes with the Internal Revenue Service despite not being authorized to work within the country. To allow people ineligible for a social security number to fulfill their tax obligations, the IRS developed the Individual Taxpayer Identification Number (ITIN) system in 1996. The ITIN is not only for unauthorized workers, but also includes all foreign-born people ineligible for a social security number. Since its inception, 6.9 million ITIN numbers have been distributed, with 70 percent of them going to Latinos (Yzaguirre 2004).

Over the course of the interviews, the issue of taxation appeared several times in conversations. I did not originally ask specific questions about it; I asked if workers had taxes deducted but not about whether they filed their taxes. However, when the issue of taxes came up, interviewees asked me if I knew how to file a tax claim. They asked me questions about the ITIN, and if I knew anyone who had filed. Workers were fearful that if they filed an ITIN claim, their employers would be notified and they would lose their jobs.

Whether semi-formal workers file for taxes or not, social security payouts are deducted from their checks. This has created a unique set of problems for the Social Security Administration (SSA) as it attempts to match funds paid with accounts. When funds cannot be matched, they are placed in the Earnings Suspense File (ESF). The Government Accountability Office (GAO) reports that four percent of all reports are placed in the ESF. The reports that SSA places in ESF are narrowly distributed in a few key industries, which the GAO notes are industries that rely on relatively 
unskilled and migrant labor. The top three employers are eating and drinking places with 17 percent, construction with 10 percent and agricultural production with seven percent (GAO 2005).

The GAO (2005) has inferred that many reports in the ESF file are related to unauthorized employment. They base this on figures from reinstatements, which is the process whereby earnings reports are matched to an individual's file. While before 1986 the percentage of reinstatement to foreign born people was 7.85 percent, by 2003 this percentage had slowly increased to $20.72 \%$. Of these, 25.58 percent are from Mexico. Not all foreign reinstatements indicate unauthorized employment, but some do. Before 1986 seven percent of foreign born workers with reinstatements had earnings before they received a social security number. Between 1986 and 2003 this percentage grew to 32 percent. This suggests a large growth in unauthorized employment in the last few decades.

The amount of money paid to social security by unauthorized immigrants is significant. Estimates reported by the New York Times are as high as seven billion dollars a year. If true, this means unauthorized workers contributions comprised 10 percent of last year's surplus (Porter 2005).

One consequence of trying to match numbers and files is that the SSA sends no-match letters to employers, informing them that the social security number provided by a worker does not match the name given by the worker. Often times, even though the letter tells the employer not to remove employees because of the no-match letter, employers become confused and/or scared and fire their staff (NELP 2004). One worker I spoke with told me that the entire housekeeping staff of one hotel where she had worked was fired after a no-match letter came in regards to one worker. Management then checked the documentation of all workers, and fired them all.

The issue of taxation has several important consequences for workers. First, most semiformal workers are low income workers who would be entitled to a refund of some of their tax money. Not receiving this money means they are taking home less disposable income. Second, as 
strategies of workers change and they move from being a target earner to a settler, their ability to demonstrate "good moral character" for the possibility of legalizing their status is diminished if they have not followed tax laws. Furthermore, their banking opportunities are limited without an ITIN number as banks need an ITIN or SS number on interest bearing accounts to report to the IRS. This means they are less able to establish credit, which has implications for access to housing, car loans, and all types of credit institutions which are integral in moving beyond a low wage day to day life.

The fear that keeps immigrants from filing taxes is not unfounded. While the IRS does not have the authority to engage in wholesale exchange of information with other federal agencies, there have been reports of the Treasury Inspector General for Tax Administration using ITIN information to prosecute immigrants. These reports come from one agency in Kentucky, but many immigrants are concerned about the risk (NELP fact sheet).

\section{Conclusion and Suggestions for Future Research}

Scholarly literature to date has provided limited theoretical understanding of informality and unauthorized immigrant labor. Understanding the complexities of the informal labor market highlights the unique situation for workers who have false documentation, pay taxes, and work in a mostly regulated atmosphere. These semi-formal workers appear to form mutually beneficial yet uncodified labor relationships with employers, rely on networks to facilitate employment, and have little understanding of taxation.

The legal changes of IRCA in 1986 suggest employers are less likely to hire workers without documentation. As false documents are relatively easy to produce, it can be expected that the category of semi-formal workers will increase. In addition, rapid gains in the Mexican population suggest that unauthorized immigration is also increasing. 
The spectrum of formality in the labor market distinguishes employers as they develop unique strategies to adapt to different situations. There is a need for research which not only further examines these strategies, but also addresses the long-term implications of such strategies. Questions which are little understood by scholars include how semi-formal strategies affect attempts to attain legal status, and their implications for future attempts to purchase homes, cars and invest in businesses.

Furthermore, future work is needed on the issue of taxation. There is strong evidence that unauthorized workers contribute substantial revenue to the federal government and Social Security, even though most are unlikely to receive the corresponding benefits. While much analysis and controversy has focused on the questions of whether or not unauthorized immigrants are a net drain on state and local finances, analysis at the federal level is needed. Furthermore, analysis on the consequences of taxes for workers is also lacking. It appears that not only do substantial numbers of migrants not file their refunds, but that Social Security no-match endangers workers present employment.

\section{Appendix: General demographics and Results of the Interviews}

The twelve participants consisted of four women and eight men. The average age of the sample is 34.75 years. The two youngest participants are 22 years old, and the oldest is 60 . The rest of the participants are within the 30 to 40 year range. The average number of years of schooling is 11.17 years. The lowest number of years of schooling is six, and the highest 16. After the preparatoria, or high school, the most common form of further education is a technical education for a specific skill.

Researchers estimate the states of Guadalajara, Nayarit, Colima, Zacatecas, Aguascalientes, and Guanajuato send between half and three quarters of the migrant flow to the United States 
(Massey et al., 1987). The majority of participants do not come from the typical sending states of western Mexico. Of the migrants interviewed, only two originate from a state in the traditional sending area - the state of Michoacan. Six participants originate from the state of Hidalgo, two from the state of Oaxaca and two from Mexico City.

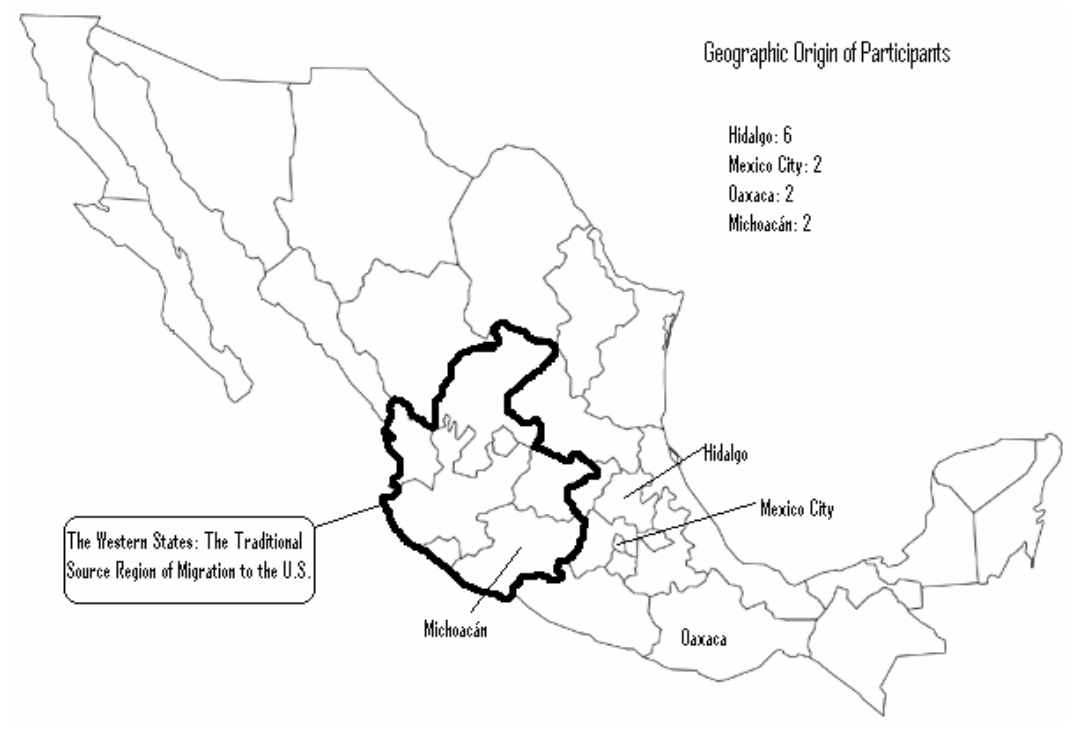

Of the eight men interviewed, six are married. At the time of the study, none of the men's wives lived in Portland. Of the four women interviewed, only one is married, and migrated at the same time as her husband. None of the women came to the United States for family reunification, a common explanation for the migration of women.

Six of the twelve respondents supported children at the time of the study. One has self supporting children, and the other five do not have children. Three of the respondents have children that live or have lived in the United States. One woman's son joined her at the age of eighteen for one year before returning to Mexico to attend the university. Another had three children-one born in Mexico and two in the United States. The third had two children who had stayed behind in Mexico, however, at the time of the interview they were in the process of entering 
the United States with their mother. The other three respondents have children in Mexico, with no plans to bring them to the United States.

In examining wages earned, I divided up counter service into two categories: local fast food and chain fast food. The reason for this is that the local fast food person made significantly more than the other fast food workers, and combining the two wages would not have been informative on the actual wage conditions of the workers. On average, the wages were highest for the one individual in local fast food. Beyond that, wages were highest in full service restaurants.

Table 4: Hours and Wages of Participants at time of Interview

\begin{tabular}{|l|l|l|l|l|l|}
\hline & $\begin{array}{l}\text { Number of } \\
\text { Participants } \\
\text { Wage }\end{array}$ & $\begin{array}{l}\text { Average } \\
\text { Hours } \\
\text { worked per } \\
\text { job }\end{array}$ & $\begin{array}{l}\text { Average } \\
\text { number of } \\
\text { jobs }\end{array}$ & $\begin{array}{l}\text { Average } \\
\text { hours } \\
\text { worked in } \\
\text { total }\end{array}$ \\
\hline $\begin{array}{l}\text { Local Fast } \\
\text { Food }\end{array}$ & 1 & 12.00 & 50 & 1 & 50 \\
\hline $\begin{array}{l}\text { Chain Fast } \\
\text { Food }\end{array}$ & 3 & 8.12 & 36.25 & 1 & 36.25 \\
\hline $\begin{array}{l}\text { Full Service } \\
\text { Restaurants }\end{array}$ & 8 & 9.58 & 35.65 & 1.625 & 57.94 \\
\hline Combined & 12 & 9.02 & & 1.42 & 53.27 \\
\hline
\end{tabular}

Workers surveyed were completely segregated by sex; all the fast food workers were women and all the full service restaurant workers were men. In addition, among the people surveyed, only men held more than one job. Indeed the men working in full service restaurants averaged 1.625 jobs, for a total average of 57.94 hours a week. The person who worked the most was working 89 hours a week. 


\section{References}

Bailey, Thomas. 1985. "A Case Study of Immigrants in the Restaurant Industry." Industrial Relations. 24 (2): 205-221.

Biernacki, Patrick and Dan Waldorf (1981). "Snowball Sampling: Problems and Techniques of Chain Referral Sampling." Sociological Methods \& Research, 10, 141-163.

Borjas, George J, Richard B Freeman and Lawrence F Katz. 1996. "Searching for the Effect of Immigration on the Labor Market.” The American Economic Review. 86 (2): 246-251.

Briggs, Vernon M, Jr. 2003. "The Economic Well-Being of Black Americans: The Overarching Influence of US Immigration Policy." The Review of Black Political Economy. 31 (1-2): 15-42.

Castell, Manuel and Alejandro Portes. 1989. "World Underneath: The Origins, Dynamics and Effects of the Informal Economy." In Alejandro Portes, Manuel Castells and Lauren A. Benton (eds) The Informal Economy: Studies in Advanced and Less Developed Countries. John Hopkins University Press: Baltimore and London

Cornelius, Wayne A. (1982) Interviewing Undocumented Immigrants: Methodological Reflections Based on Fieldwork in Mexico and the U.S. International Migration Review, 16, 378-411.

Davis, Benjamin and Paul Winters. 2001. "Gender, Networks and Mexico-US Migration." The Journal of Development Studies 38 (2): 1-26.

Davis, Benjamin Guy Stecklov and Paul Winters. 2002. "Domestic and international migration from rural Mexico: Disaggregating the effects of network structure and composition.” Population Studies 56: 291-309.

Edwards, Richard (1979) Contested Terrain: The Transformation of the Workplace in the Twentieth Century. New York: Basic Books.

Enchautegui, Maria E. 2002. "Household Members and Employment Outcomes of Recent Immigrants: A Network Approach.” Social Science Quarterly 83 (2): 594-611. 
Government Accountability Office (GAO). 2005. "Social Security: Better Coordination among Federal Agencies Could Reduce Unidentified Earnings Reports.” GAO-05-154

Hagan, Jacqueline Maria. 1994. Deciding to be Legal: A Maya Community in Houston. Philadelphia: Temple University Press.

Hagan, Jacqueline Maria. 1998. "Social Networks, Gender and Immigrant Incorporation: Resources and Constraints." American Sociological Review, 63 (1): 55-67.

Hondagneu-Sotelo, Pierrette. 2001. Domestica: Immigrant Workers Cleaning and Caring in the Shadows of Affluence. Berkeley: University of California Press.

Hodagneu-Sotelo, Pierrette. 1994. Gendered Transitions: Mexican Experiences of Immigration. Berkeley: University of California Press.

Krissman, Fred. 2000. "Immigrant Labor Recruitment: US Agribusiness and Undocumented Migration from Mexico.” In Nancy Foner, Ruben G Rumbaut and Steven G Gold (eds) Migration Research for a New Century: Multidisciplinary Perspectives. pp. 277-300. New York: Russell Sage Foundation

Lopez-Garza, Marta. 2001. "A Study of the Informal Economy and Latina/o Immigrants in Greater Los Angeles.” In Marta Lopez-Garza and David R. Diaz (eds.) Asian and Latino Immigrants in a Restructuring Economy: The Metamorphosis of Southern California. pp. 141-168. Stanford: Stanford UP

Love, John F. 1986. McDonald's: Bebind the Arches. New York Toronto London Sydney Auckland: Bantam Books

Marcelli, Enrico. 2004. "Unauthorized Mexican Immigration, Day Labour and other Lower-wage Informal Employment in California." Regional Studies 38(1), pp. 1-13.

Martin, Philip L. 1993. “The Missing Bridge: How Immigrant Networks Keep Americans Out of Dirty Jobs." Population and Environment: A Journal of Interdisciplinary Studies. 14(6) 
Massey, Douglas S., Rafael Alarcon, Jorge Durand and Humberto Gonzalez. 1987. Return to Aztlan. Berkeley: University of California Press

Massey, Douglas S. 1987. The Ethnosurvey in Theory and Practice. International Migration Review. 21 (4): 1498-1522.

Massey, Douglas S., Joaquin Arango, Graeme Hugo, Ali Kouaouci, Adela Pellegrino and J Edward Taylor. 1993. “Theories of International Migration: A Review and Appraisal.” Population and Development Review. 19 (3): 431-466

Massey, Douglas S and Kristin E Espinosa. 1997. "What's Driving Mexico-US Migration? A Theoretical, Empirical and Policy Analysis." The American Journal of Sociology. 102 (4): 939999.

Massey, Douglas S., Jorge Durand, and Nolan J. Malone. 2002. Beyond Smoke and Mirrors: Mexican Immigration in an Era of Economic Integration. New York: Russell Sage Foundation

Munshi, Kaivan. 2003. "Networks in the Modern Economy: Mexican Migrants in the U.S. Labor Market." The Quarterly Journal of Economics. 118 (2): 549-599.

National Employment Law Project (NELP). 2004. "Fact Sheet for Workers." Nov. Available at www.nelp.org last accessed April 72005

Passel, Jeffrey S. 2005. "Estimates of the Size and Characteristics of the Undocumented Population." Washington D.C.: Pew Hispanic Center Report. March 21. Available at www.pewhispanic.org

Piore, Michael J. 1979. Birds of Passage. Cambridge: Cambridge UP

Porter, Eduardo. 2005. "Illegal Immigrants are Bolstering Social Security with Billions." The New York Times April 5, 2005: p. A1.

Portes, Alejandro and Saskia Sassen-Koob. 1987. "Making it Underground: Comparative Material on the Informal Sector in Western Market Economies.” The American Journal of Sociology. 93 
(1), pp. 30-61.

Portes, Alejandro, Manuel Castells and Lauren A. Benton. 1989. The Informal Economy: Studies in Advanced and Less Developed Countries. John Hopkins University Press: Baltimore and London

Reich, Michael, David M. Gordon and Richard C. Edwards. 1973. "Dual Labor Markets: A Theory of Labor Market Segmentation.” American Economic Review. 63 (2): 359-365.

Rosales, Grace A. 2001. "Labor Behind the Door: Domestic Workers in Urban and Suburban Households." In Marta Lopez-Garza and David R. Diaz (eds.) Asian and Latino Immigrants in a Restructuring Economy: The Metamorphosis of Southern California. pp. 169-187. Stanford: Stanford UP

Sassen Koob, Saskia. 1989. “New York City’s Informal Economy.” In Alejandro Portes, Manuel Castells and Lauren A. Benton (eds) The Informal Economy: Studies in Advanced and Less Developed Countries. pp. 60-77. John Hopkins University Press: Baltimore and London

Simcox, David. 1997. "Immigration and Informalization of the Economy: Enrichment or Atomization of Community" Population and Environment: A Journal of Interdisciplinary Studies. 18(3), pp. 255-281

Stepick, Alex. 1989. "Miami’s Two Informal Sectors" In Alejandro Portes, Manuel Castells and Lauren A. Benton (eds) The Informal Economy: Studies in Advanced and Less Developed Countries. pp. 111-134. John Hopkins University Press: Baltimore and London

Suro, Robert. 2005. "Survey of Mexican Migrants: Attitudes about Immigration and Major Demographic Characteristics.” Pew Hispanic Center

Valenzuela, Abel Jr. 2003. “Day Labor Work.” Annual Review of Sociology. 29: 307-333.

Van Giezen, Robert W. 1994. "Occupational wages in the fast food industry." Monthly Labor Review. August 1994 pp. 24-30.

Weber, Clair M. 2001. "Latino Street Vendors in Los Angeles: Heterogeneous Alliances, 
Community-based Activism, and the State.” In Marta Lopez-Garza and David R. Diaz (eds.) Asian and Latino Immigrants in a Restructuring Economy: The Metamorphosis of Southern California. pp. 141-168. Stanford: Stanford UP

Williams, Colin C. and J. Windebank. 1998. Informal Employment in the Advanced Economies: Implications for Work and Welfare. Routledge: New York 